\title{
The Effect of Using Directed Reading Thinking Activity (DRTA) Strategy on the Tenth Grade Students' Reading Comprehension Achievement at MA Unggulan Nuris Jember
}

\author{
Frida Hayu Novendiana, Zakiyah Tasnim, Bambang Arya Wijaputra \\ Language and Arts Education Program, The Faculty of Teacher Training and Education, \\ University of Jember \\ Jln. Kalimantan 37, Sumbersari, Jember, Jawa Timur 68121 \\ E-mail: zakiyahtasnim.fkip@,unej.ac.id
}

\begin{abstract}
The aim of this research was to know whether or not there was a significant effect of using Directed Reading Thinking Activity (DRTA) strategy on the tenth grade students at MA Unggulan Nuris Jember. The research design used was quasi experimental research specifically post test only non equivalent group design. The respondent of the research was chosen by using cluster random sampling by a lottery. The students of XIPA A as the experimental group and X PK $B$ as the control group. The data was collected by interview, documentation and administering reading comprehension test. Then the data collected were analyzed by using independentt sample T-test. It was known that the mean score of the experimental group was 78.80 and the mean score of the control group was 73.73 . In the output of the t-test column, it was shown that the significant value was 0.03. It was lower than 0.05. It means that the mean scores of the two classes (experimental and control groups) were different. Therefore, there was a difference between the experimental class and the control class. In conclusion, the use of Directed Reading Thinking Activity (DRTA) strategy was a significantly affected on the tenth grade students' reading comprehension achievement tat MA Unggulan Nuris Jember,
\end{abstract}

Keywords: reading comprehension achivement, DRTA strategy

Introduction

Language is a system of communication that is used by people to express their thought and feeling. One of the languages which can be used for communication with other people in the world is English. It is used and learnt in many countries. According to Brown [2] English is used in many sectors. One of them is in education sector.

English is a compulsory subject for students from junior high school until university level. This condition requires English teachers to give good atmosphere to the students to learn the language well. In learning English, there are four language skills that should be mastered by the students, they are reading, speaking, writing and listening. The four skills should be taught in order to help the students use English. Based on the four language skills above, reading is one of the four primary skills that students should master. Grellet [8] stated that reading is as the process of understanding of a reading text. It means that as a reader we should find the meaning and understand the massage stated in the passage.

In order to obtain the information and knowledge, students are not only able to understand the reading text but also comprehend the content of the reading text. Reading comprehension in teaching learning process is badly needed to be mastered by the students to gain information and knowledge in the written text. Students must know exactly what they are reading and finding the meaning from the text. In reading comprehension students can interact with written information in order to improve and add some information. According to Woolley [10], reading comprehension is the process of making meaning from text. To make the students easier in comprehending the reading text, the most important thing is the teacher's role in teaching learning process especially in choosing teaching strategy. For example, the teacher provides an appropriate teaching strategy which can help the students understand the information from the English reading text and doing the exercise as well. The strategy is used to help the students to activate their background knowledge, connect ideas, focus on the topic and help them get and remember the general information and specific information after English reading activity.

Teaching method is one of significant factors in motivating students' achievement in reading. The teacher should apply an effective strategy to make students interested in reading activity. There are many strategies which can be applied in teaching reading. One of them is Directed Reading Thinking Activity (DRTA) strategy. Directed Reading Thinking Activity (DRTA) was developed by Stauffer [9] as a framework for teaching reading, which stresses students' abilities to read reflectively and to use prediction. This strategy involves the students to be active in making prediction. The teacher can build their prior knowledge by asking them some questions related to reading text. Bos and Vaughn [2] stated that the students can get a little information related to their prior knowledge they have already had from the teacher's question. There are three steps of DRTA strategy, they are prediction step, guided silent reading step and proving step.

In prediction step,the teacher sets the students for reading and helps them think about what they are going to read before starting. The students learn to predict about what they are going to read. Prediction deals with any speculation about the content of a reading text. According to Gillet and Temple [7] prediction requires the students to relate their 
prior knowledge to the reading task at hand and to form expectation they will apply to the reading. It means that in prediction, the form of expectation can be right or wrong based on their knowledge. The next step is guided silent reading, in this step the teacher asks the students to read the material silently. They keep reading until they find any information which is related to their prediction are right or wrong. They can replace their wrong predictions with a new hypothesis in the guided silent reading step. The last step is proving step, where students have to prove their prediction about some information they have read from the text. The student can prove by mentioning which sentences or words clarify their prediction. According to Gillet and Temple [7], students are asked to prove their ideas by finding and reading a sentence aloud. This statement means that the students must read to know which information that they want to clarify orally in order to prove their prediction and give the reasons why they should change their predictions.

The respondent of this study were the tenth grade students of MA Unggulan Nuris Jember. Based on the 2013 Curriculum, the text genre for the tenth grade students in the odd semester is narrative text. Therefore in this study the researcher focused on narrative text genre.

\section{Research Method}

The design of this research was quasi experimental design with non-equivalent groups post-test-only design. This research was intended to know whether or not there was an effect of using Directed Reading Thinking Activiy (DRTA ) strategy on the tenth grade students' reading comprehension achievement at MA Unggulan Nuris Jember. There were two groups that were investigated in this research, namely the experimental group and the control group. Fraenkle, Wallen, Hyun [6] state that quasiexperimental research is a research design which does not include the use of random assignment. In this research, the experimental group was taught reading by using Directed Reading Thinking Activiy (DRTA) strategy while the control group was taught reading by using the conventional technique commonly used by the teacher that is scientific approach .

The area of this research was chosen purposively, that was MA Unggulan Nuris Jember. The reasons of choosing this school were the English teacher of the tenth grade never used Directed Reading Thinking Activity (DRTA ) strategy in teaching reading and both the headmaster and the English teacher gave permission to the researcher to conduct this experimental research.

The respondents of the experimental group and the control group of this research were determined by using cluster random sampling by lottery since the population was homogeneous. The result was X IPA A as the experimental group and X IPA B as the control group.

There were two kinds of data collection method used in this research, namely primary data and supporting data. The primary data were obtained from reading post-test, while the supporting data were obtained from the interview with the English teacher and the documentation. The researcher also conducted the try out reading test to a class which did not belong to the experimental group and the control group that was X PK B. The try out was done to know the reliability of the test items, the index difficulty of the test items, whether the time allotted was enough or not and whether the instruction of the test items was clear or not to understand.

The data analysis method used in this research was Independent sample t-test formula to analyze the results of the students' scores of the reading post test. The analysis intended to know whether or not there was a difference between the mean of the two groups (the experimental group and the control group). Based on SPSS data output, there were two stages of analysis in the Independent Sample t-test, that were the test of Equality of Variances $\left(\mathrm{F}_{\text {test }}\right)$ and the test of Equality of Mean Score $\left(\mathrm{T}_{\text {test }}\right)$. They were done to know whether or not there was an effect of using Directed Reading Thinking Activity DRTA strategy.

\section{Research Results}

Based on the analysis of the data by using Independent sample t-test counted by SPSS software, the output of the analysis could be seen in table 1 below. The table was about "Group Statistics" that gave information related to the number of the students in each group $(\mathrm{N})$, the mean score of each class, standard deviation and standard error mean.

Table 1 Group Statistic

\begin{tabular}{|l|l|l|l|l|}
\hline CLASS & $\mathrm{N}$ & Mean & $\begin{array}{l}\text { Std. } \\
\text { Deviation }\end{array}$ & $\begin{array}{l}\text { Std. Error } \\
\text { Mean }\end{array}$ \\
\hline $\begin{array}{l}\text { SCORE } \\
\begin{array}{l}\text { EXPERIMENTAL } \\
\text { GROUP } \\
\text { CONTROL GROUP }\end{array}\end{array}$ & 30 & 78.80 & 9.463 & 1.728 \\
\hline
\end{tabular}




\begin{tabular}{|c|c|c|c|c|c|c|c|}
\hline \begin{tabular}{|l} 
Equal \\
Variance \\
not \\
Assumed
\end{tabular} & 2.203 & \begin{tabular}{|l}
57.50 \\
9
\end{tabular} & .032 & 5.067 & 2.300 & .461 & 9.672 \\
\hline
\end{tabular}

Based on Table 2 above showed the analysis result of the primary data taken from post-test by using independent sample t-test to know the significant effect of using Directed Reading Thinking Activity (DRTA) strategy on the students' reading comprehension achievement. To read the table above, the first step was analyzing two variances whether they were equal or not $\left(\mathrm{F}_{\text {test }}\right)$. The second step was analyzing two groups whether the mean scores were the same or not $\left(\mathrm{T}_{\text {test }}\right)$. The first column on the table above showed that $\mathrm{F}$ value was 0.558 with the sig. Value 0.446 . Because the sig. value was higher than 0.05 , the variances of the two group (experimental group and control group) were the same. The equal variances assumed should be read because the two classes were equal in the score of their reading test

In the second column, it was shown that the sig.value was 0.03 which lower than 0.05 ( $\mathrm{sig}<0.05)$. It means that the scores of the two groups were different.

The result of the analysis on the students' reading showed that the experimental group which was given a treatment that was Directed Reading Thinking Activity (DRTA) showed better performance during the test than the control group. It could be seen from table 2 that the significant value was $0.03<0.05$. It means that the mean score of the two groups were different. Table 1 showed that the mean score of experimental group was 78.80 and 73.73 for the control group. It proved that there were a significant mean different between the experimental group and the control groups. Therefore, the research alternative hypothesis saying that "There is a significant effect of using Directed Reading Thinking Activity (DRTA) strategy on the tenth grade students' reading comprehension achievement at MA Nuris in the 2016/2017 academic year" was accepted.

The present research result was relevant with the theory suggested by Stauffer [9] who states that the use of Directed Reading Thinking Activity (DRTA) strategy is kind of general reading strategy to guide the students having critical thinking process while reading through the reading text. The students' critical thinking skill is expressed when the students try to judge their own prediction. DRTA also helps the students of the experimental group have better understanding in the process of comprehending the text. It was evidence that DRTA strategy in teaching reading was able to make the students become active readers.

Further, the results of present research using Directed Reading Thinking Activity (DRTA) as strategy also supported by some previous research results which had proved that the strategy were able to affect the students' reading comprehension achievement. For example an experimental research which had conducted by Androveda [1] showing that the sig. value 0.02 it was lower than 0.05 . It proved that there is a significant effect of using Directed Reading Thinking Activity (DRTA) strategy on the tenth grade students' reading comprehension achievement.
Furthermore, Candrawati [4] also used an experimental research in different sample. She chose the Junior High School as the sample. Her study proved that the use of Directed Reading Thinking Activity (DRTA) strategy gave a significant effect on the students' reading comprehension achievement. In addition, Erliana [5] conducted an experimental research entitled Improving Reading through Directed Reading Thinking Activity (DRTA) Strategy. It was found out that DRTA was effective and suitable strategy in improving reading in terms of providing the students with opportunity to utilize reading strategy, to enhance self confidence and to produce independent learners.

In conclusion, Directed Reading Thinking Activity (DRTA) strategy was an appropriate strategy that had a significant effect on the students' reading comprehension achievement. Based on the data analysis result and the discussion above, it proved that the use of Directed Reading Thinking Activity had a significant effect on the tenth grade students reading comprehension achievement at MA Unggulan Nuris in the 2016/2017 academic year.

\section{Conclusion and Suggestion}

Based on the data analysis result, hypothesis verification and discussion in the previous chapter, it could be concluded that there was a significant effect of using Directed Reading Thinking Activity (DRTA) Strategy of the tenth grade students' reading comprehension achievement at MA Unggulan Nuris in the 2016/2017 academic year. It means that the experimental group who was taught reading comprehension by using Directed Reading Thinking Activity (DRTA) got better reading comprehension achievement than the control group that was taught by using conventional strategy.

\section{Acknowledgement}

This article is the summary of a study entitled "The Effect of Using Directed Reading Thinking Activity (DRTA) Strategy on the Tenth Grade Students' Reading Comprehension Achievement at MA Unggulan Nuris Jember"

\section{References}

[1] Androveda, G.. N. 2015. The Effect of Using Directed Reading Thinking Activity on the Tenth grade Students' Reading Comprehension Achievement at SMAN 1 Yosowilangun Lumajang. Jember University.

[2] Bos,C. N. and Vaughn, S. 1991. Strategies for Teaching Students with Learning and Behavior Problems. Boston; Allyn and Bacon, A division of Simon ans Schuster. Inc.

[3] Brown, H Douglas. 2003. Language Assessment: Principles and Classroom Practices. San Fransisco, California: Pearson Education.

[4] Candrawati, D. K. F. 2010. The Effect of Using Directed Reading Thinking Activity on the Tenth grade Students' Reading Comprehension Achievement at SMP N 5 Tanggul. Jember: Jember University.

[5] Erliana, S. 2011. Improving Reading Comprehension Directed Reading Thinking Activity (DRTA) strateg. Journal on English as Foreign Language, Volume 1, Number 1,March 2001 Islamic state of 
Palangkaraya: available at https://fauziahnnor.file.wordpress.com/ 2013/03/santi-erliana.pdf. (Retrieved on Oct 1,2016)

[6] Fraenkle, Wallen, and Hyun. 2012. How to Design and Evaluate Research in Education. Eight edition. New York: McGraw-Hill Companies, Inc., enesaenglish.blogspot.com/search/label/narrative \%20text?\&max-results=5 Retrieved April 20,2016

[7] Gillet, J. W., and Temple, C. 1990. Understanding reading problems. Assessment and instruction. Third edition. New York. Harper Collin Publisher

[8] Grellet, F. 1996. Developing Reading Skill: A practice Guide to Reading Comprehension. Cambridge. Cambridge University Press.

[9] Stauffer, R. G. (1969). Directing reading maturity as a cognitive process. New York: Harper \& Row.

[10] Wolley, G.. 2011. Reading Comprehension. Assisting Children with learning difficulties. Springer. Online http//www.springer.com//97894-007-1173-0

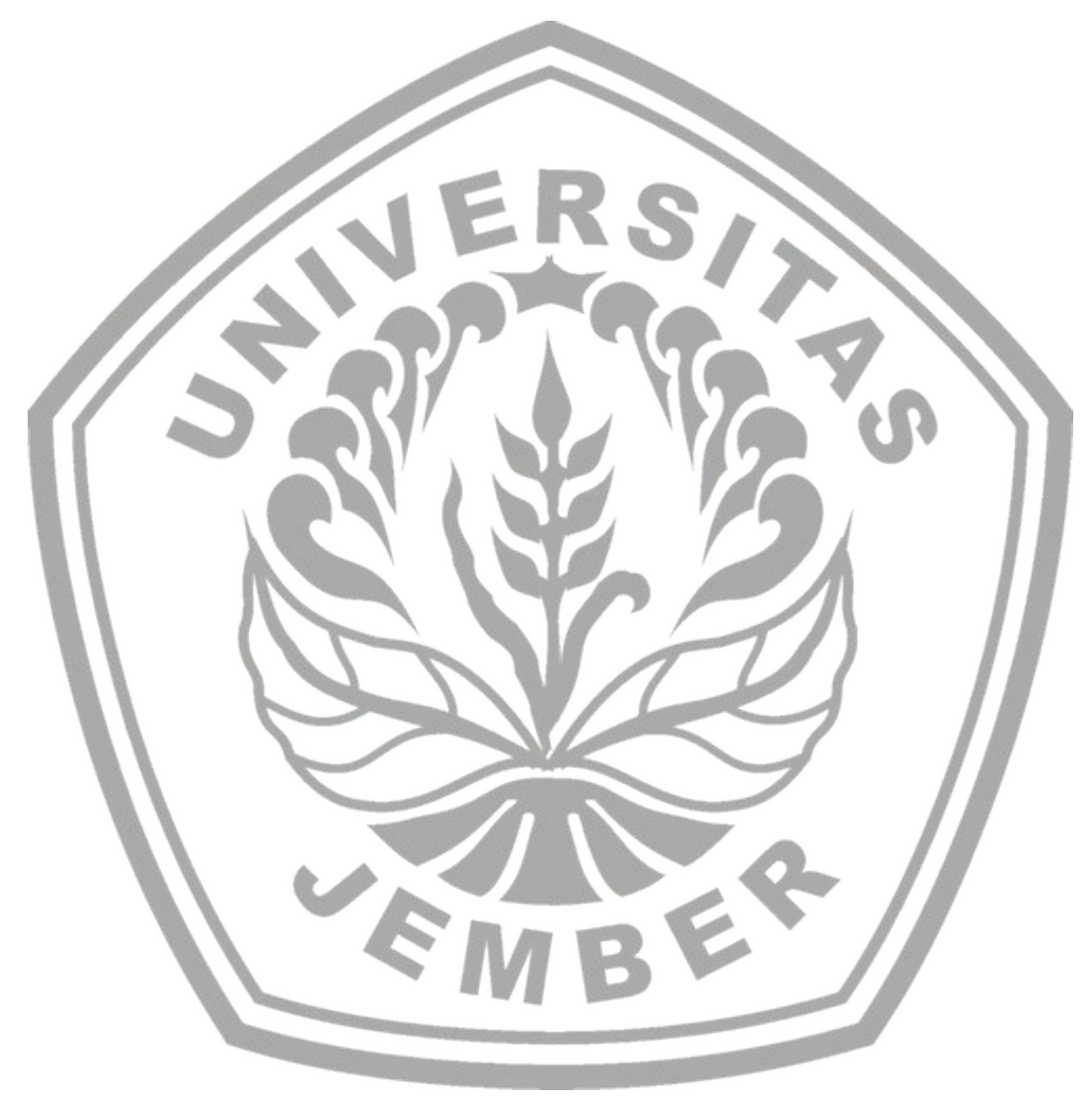

